\title{
The Capacitated Sustainable EOQ Models: Models Considering Tax Emissions
}

\author{
S. K. B. Maulana*, D. M. Utama, M. S Asrofi, I. S. Ningrum, N. Alba, H. A. Ahfa, \\ T. A. Zein \\ Industrial Engineering Department, Universitas Muhammadiyah Malang, Indonesia \\ Jl. Raya Tlogomas No. 246, Malang 65144, Indonesia \\ *Corresponding author: kurniamaulana2@gmail.ac.id
}

\section{ARTICLE INFO}

Article history

Received January 6, 2019

Revised September 28, 2019

Accepted September 29, 2019

Available Online September 30, 2019

Keywords

Inventory

Lot size

EOQ models

Sustainability

Capital constraints

\begin{abstract}
The study investigated problems of determining the lot size by considering sustainability and capital constraints for purchasing raw materials and taxes. Using the Sustainable EOQ (SEOQ) models that considered environmental aspects, the researchers also evaluated the capital constraints. The proposed models were used to minimize total inventory costs. In this study, there was a practical numerical analysis and sensitivity analysis to help decision-makers and inventory problems. Finally, the experimental results showed that the proposed models were effectively used to solve the problems.
\end{abstract}

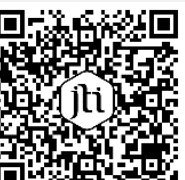

\section{Introduction}

Inventory is the primary key for a company to support its smooth production $[1,2]$. Inventory has a vital role in the supply chain [3]. Besides, this has an impact on the company's operating costs [4, 5]. Several approaches have been proposed to solve inventory problems. These include Economic Order Quantity (EOQ), heuristic algorithms [6], and dynamic programming [7, 8]. Nowadays, environmental issues have become the concern of all companies and the world [9, 10]. Companies are required to pay attention to environmental aspects, including carbon emissions and waste [11]. Di In developed countries, the government provides a tax policy for carbon emissions to produce emissions and waste [12]. It is intended to raise company awareness of environmental problems [13, 14]. Recently, carbon emissions have become an essential issue in the industrial sectors. It includes transportation, inventory, and storage [15, 16]. Through inventory management, companies can control carbon emissions and economic aspects [17]. Researchers have currently shown their keen interest in Sustainable EOQ (SEOQ) [18].

In inventory, the SEOQ model is a lot size method used to determine economic orders by considering environmental aspects [19]. This model has to economically balance the financial perspective with the environmental perspective so that the industry can determine the appropriate policy that supports sustainability. There have been many studies about inventory issues that accommodate carbon emissions, such as Chen, et al. (2013), Jaber, et al. (2017), dan He, et al. (2015). In general, the studies consider issues of 
carbon emission impacts, order frequency, and storage amount [23, 24]. Bauer, et al. (2010) proposed the SEOQ model by considering transportation costs. Subsequently, some researchers developed the model by adding tax cost on environmental impacts [26, 27]. Furthermore, some researchers also included environmental and tax costs in the procurement inventory model [28] and the production inventory model [29,30]. Up to the present day, there have been several studies investigating the relationship between inventory [31] and capital constraints [32]. Raturi and Singhal (1990) developed the multiitem EOQ model by considering shortage cost, production, and capital constraints. Asadabadi (2016) also proposed the EOQ model with capital constraints for purchasing raw materials.

Although research on SEOQ has been flourishing lately, there have not been any studies that discuss SEOQ with capital restrictions for purchase and emission taxes. It has created a considerable amount of uncertainty about the relationship between SEOQ and capital constraints. Based on the description mentioned earlier, one way to overcome the problems is to accommodate capital limitation factors into the SEOQ models. The solution to the problems is based on the capital purchase function, which is the cost for the company's operations. Therefore, a new approach is needed to investigate the effect of capital in the SEOQ models. In the current study, we developed SEOQ models that considered carbon emissions by including capital restrictions on purchasing goods. This study aimed to develop a more sophisticated method to solve the problems of determining lot size by considering environmental impacts and capital constraints. Therefore, this research generated new insights in inventory, especially the SEOQ models with capital constraints. In addition, this study was intended to contribute to research on SEOQ by exposing the effects of capital on the number of lot sizes.

\section{Methods}

\subsection{Assumptions and Notations}

Assumptions of the SEOQ problems consist of (1) demands, order cost, purchasing cost, holding cost, tax fees, total emissions, and total capital in a fixed period; (2) components of the assumption that are deterministic; (3) each model is used for 1 item emission product; (4) tax cost per one emission unit; and (5) capital used is the capital for a purchase or emission tax. The notations used in the models include:

$\lambda \quad$ : Demands

$K \quad$ : Cost per order

$c \quad$ : Purchasing cost per unit

$h \quad$ : Holding cost per unit

$f \quad$ : Total emissions from ordering

$v \quad$ : Total emissions from purchasing

$g \quad$ : Total emissions from holding

$\beta \quad$ : Lagrange multipliers

$M \quad$ : Capital

p : Emission tax cost

$Q \quad$ : Number of orders

$Q_{s} \quad$ : Optimal sustainable number of orders without tax

$Q_{s p} \quad$ : Optimal sustainable number of orders with tax

$Q_{s m} \quad$ : Optimal sustainable number of orders without tax; with capital constrain

$Q_{s p m} \quad$ : Optimal sustainable number of orders with tax and capital constrain

TIC : Total inventory cost 
$T I C\left(Q_{s}\right)$ : Optimum total inventory cost without tax

$T I C\left(Q_{s p}\right):$ Optimum total inventory cost with tax

$T I C\left(Q_{s m}\right)$ : Optimum total inventory cost without tax; with capital constrains

$T I C\left(Q_{s p m}\right)$ : Optimum total inventory cost with tax and capital constraint

\subsection{Proposed SEOQ Model without Limits}

In terms of the proposed SEOQ model without limit, this study developed two SEOQ models, namely SEOQ model without tax and the SEOQ model with the tax on carbon emissions.

\subsubsection{SEOQ without Tax}

In this model, the researchers considered the costs included in the sustainable inventory, such as the fixed cost of an environmental impact for each cycle, order cost, purchasing, and holding cost. The total inventory cost is formulated as follows (1):

$$
T I C=\frac{(K+f) \lambda}{Q}+\lambda(c+v)+\frac{(h+g) Q}{2}
$$

To gain the optimal $Q$ for the SEOQ model without tax, equation (1) is differentiated to $Q$. The result is presented in equation (2).

$$
Q_{S}=\sqrt{\frac{2(K+f) \lambda}{(h+g)}}
$$

Further, equation (2) is substituted to equation (1) to determine the SEOQ total inventory cost (TIC) without tax $\left(\operatorname{TIC}\left(Q_{s}\right)\right)$. TIC $\left(Q_{s}\right)$ is shown in equation (3).

$$
\operatorname{TIC}\left(Q_{s}\right)=\lambda(c+v)+\sqrt{2(K+f) \lambda(h+g)}
$$

\subsubsection{SEOQ with Tax}

In the problem of SEOQ with emission tax, the study considered emission tax. The SEOQ model with tax is formulated in equation (4).

$$
T I C=\frac{(K+p f) \lambda}{Q}+\lambda(c+p v)+\frac{(h+p g) Q}{2}
$$

Equation (4) is differentiated to $\mathrm{Q}$ to produce the optimal $\mathrm{Q}$ for the SEOQ model with emission tax. The result is presented in equation (5).

$$
Q_{s p}=\sqrt{\frac{2(K+p f) \lambda}{(h+p g)}}
$$

Further, equation (2) is substituted to equation (1) to determine the total inventory cost (TIC) without tax $\left(\operatorname{TIC}\left(Q_{S}\right)\right)$. TIC $\left(Q_{S}\right)$ is shown in equation (3).

Further, equation (5) is substituted to equation (4) to determine the SEOQ total inventory cost (TIC) with emission tax $\left(\operatorname{TIC}\left(Q_{s p}\right)\right)$. TIC $\left(Q_{s p}\right)$ is displayed in equation (6).

$$
\operatorname{TIC}\left(Q_{s p}\right)=\lambda(c+p v)+\sqrt{2(K+p f) \lambda(h+p g)}
$$




\subsection{Proposed SEOQ Model with Capital Constraint}

The researchers developed another model concerning capital constraint. The capital referred to the cost used in purchasing raw materials and purchase emission tax. Equation (7) denotes the capital of raw material purchase without emission tax. Equation (8) represents the capital of raw material purchase without emission tax.

$M=Q \times(c+v)$

$M=Q \times(c+p v)$

The SEOQ model with capital constraints comprised two types: capital with tax and capital without tax, which has been developed by adding a constraint function, i.e., capital constraints.

\subsubsection{Proposed SEOQ Model without Tax and with Capital Constraint}

The study employed the Lagrange function to minimize the total inventory cost against the constraint. The model of total inventory cost in equation (1) is added to the constraint function in equation (7). The Lagrange function of the proposed SEOQ model without tax and with capital constraint is displayed in equation (9):

$$
L(Q, \beta)=\frac{(K+f) \lambda}{Q}+\lambda(c+v)+\frac{(h+g) Q}{2}-\beta(Q(c+v)-M)
$$

Further, equation (9) is differentiated partially to $\mathrm{Q}$ and $\beta$. The results are formulated in equations (10) and 11.

$$
\begin{aligned}
& Q_{s m}=\sqrt{\frac{2(K+f) \lambda}{(2 c+2 v) \beta-g-h}} \\
& \beta=\frac{-2(c+v)^{2}(K+f) \lambda+M^{2}(h+g)}{2 M^{2}(c+v)}
\end{aligned}
$$

Equations (10) and (11) are substituted to equation (4) to determine the total inventory cost (TIC) with capital constrain $\left(\operatorname{TIC}\left(Q_{s m}\right)\right)$. TIC $\left(Q_{s m}\right)$ is presented in equation (12).

$$
\operatorname{TIC}\left(Q_{s m}\right)=\frac{(c+v)(\lambda \sqrt{(2 c+2 v) \beta-g-h}+\beta \sqrt{2 \lambda(K+f)}}{\sqrt{(2 c+2 v) \beta-g-h}}
$$

\subsubsection{Sustainable SEOQ Model with Tax and Capital Constrain}

In the sustainable SEOQ model with tax and capital constraint, the researchers developed the Lagrange formula from equation (4) by adding the constraining factor, i.e., equation (8). As a result, it is presented in equation (13).

$$
L(Q, \beta)=\frac{(K+p f) \lambda}{Q}+\lambda(c+p v)+\frac{(h+p g) Q}{2}-\beta(Q(c+p v)-M)
$$


Then, equation (13) is differentiated partially to $\mathrm{Q}$ and $\beta$. The result is formulated in equations (14) and (15). TIC $\left(Q_{\text {spm }}\right)$ is displayed in equation (16).

$$
\begin{aligned}
& Q_{s p m}=\sqrt{\frac{2(K+p f) \lambda}{(2 c+2 p v) \beta-p g-h}} \\
& \beta=\frac{-2(c+p v)^{2}(K+p f) \lambda+M^{2}(h+p g)}{2 M^{2}(c+p v)} \\
& \operatorname{TIC}\left(Q_{\text {spm }}\right)=\frac{(c+p v)(\lambda \sqrt{(2 c+2 p v) \beta-p g-h}+\beta \sqrt{2 \lambda(K+p f)}}{\sqrt{(2 c+2 p v) \beta-p g-h}}
\end{aligned}
$$

\subsection{Numerical Experiment Procedure}

This section shows the numerical experiment procedure on the proposed SEOQ models. The experiment was carried out to test the sensitivity of the proposed models. The data are presented in Table 1.

Table 1. Experiment Data

\begin{tabular}{ccc}
\hline Variable & Unit & Value \\
$\lambda$ & $\mathrm{Kg}$ & 50 \\
$K$ & $\$ /$ order & 40 \\
$c$ & $\$ / \mathrm{kg}$ & 12 \\
$p$ & $\$ / \mathrm{kg}$ & 2 \\
$h$ & $\$ / \mathrm{kg}$ & 2 \\
$f$ & $\$ / \mathrm{kgCO}_{2}$ & 60 \\
$v$ & $\$ / \mathrm{kgCO}_{2}$ & 5 \\
$g$ & $\$ / \mathrm{KgCO}_{2}$ & 1 \\
\hline
\end{tabular}

In the numerical experiment, this study used 20 variants of capital purchase data and emissions tax. The experiment was also conducted to find out the effects of $Q$ lot size on the inventory cost.

\section{Results and Discussion}

\subsection{Numerical Analysis}

Table 2 and Table 3 contain the results of the experiments using the four proposed models. Table 2 recapitulates the results of the SEOQ model without tax. The findings indicate that ordering lots of SEOQ models without capital constraint reaches 58 units for each order annually. The total inventory cost is as much as $\$ 1023,2$. According to the SEOQ experiment without tax in Table 2, if the available capital is relatively small, the lot size of orders is comparatively small. On the other hand, if the capital is relatively big, the lot size of orders is also relatively big. As reflected in Fig. 3, if $\beta>0$, Q is optimal by using equation (2). Conversely, if $\beta<0$, equation (12) is employed.

Table 3 summarizes the results of the SEOQ model with tax. The findings show that the number of ordering lot of SEOQ model without capital constraints obtains 64 units per order annually. The total inventory cost is $\$ 1353$. According to the SEOQ experiment without tax in Table 3, if the available capital is relatively small, the lot size of orders is relatively small. However, if the capital is relatively big, the lot size is also relatively big. According to Fig. 3 , if $\beta>0$ is optimal by using equation (5). Nonetheless, if $\beta<0$, equation (15) is used. 
Table 2. Experiment Results of SEOQ without Tax SEOQ without tax

\begin{tabular}{ccccc} 
Without capital constraint & \multicolumn{4}{c}{ With capital constraint } \\
\hline$Q_{s}$ & $M$ & $\beta$ & $Q_{s m}$ & $T I C\left(Q_{s m}\right)$ \\
\hline & 50 & -33.910 & 3 & 2555.1 \\
& 150 & -3.680 & 9 & 1430.1 \\
& 250 & -1.270 & 15 & 1212.2 \\
& 350 & -0.600 & 21 & 1123.8 \\
& 450 & -0.330 & 27 & 1078.7 \\
& 550 & -0.190 & 32 & 1053.1 \\
& 650 & -0.110 & 39 & 1038.1 \\
& 750 & -0.060 & 45 & 1029.5 \\
& 850 & -0.020 & 53 & 1024.9 \\
& 950 & -0.010 & 55 & 1023.3 \\
& 1050 & 0.010 & 62 & 1023.6 \\
& 1150 & 0.020 & 66 & 1025.3 \\
& 1250 & 0.030 & 72 & 1028.2 \\
& 1350 & 0.041 & 79 & 1032.1 \\
& 1450 & 0.047 & 85 & 1036.6 \\
& 1550 & 0.052 & 91 & 1041.6 \\
& 1650 & 0.057 & 98 & 1047.1 \\
& 1750 & 0.060 & 103 & 1053.0 \\
& 1850 & 0.063 & 108 & 1059.2 \\
& 1950 & 0.065 & 113 & 1065.6
\end{tabular}

Table 3. Experiment Results of SEOQ with Tax SEOQ without tax

\begin{tabular}{|c|c|c|c|c|c|}
\hline \multicolumn{6}{|c|}{ SEOQ without tax } \\
\hline \multicolumn{3}{|c|}{ Without capital constraint } & \multicolumn{3}{|c|}{ With capital constraint } \\
\hline$Q_{s p}$ & $T I C\left(Q_{s p}\right)$ & $M$ & $\beta$ & $Q_{\text {spm }}$ & $T I C\left(Q_{s p m}\right)$ \\
\hline \multirow{20}{*}{64} & \multirow{20}{*}{1353} & 50 & -70.309 & 3 & 4897.6 \\
\hline & & 150 & -7.731 & 7 & 2287.8 \\
\hline & & 250 & -2.725 & 12 & 1828.8 \\
\hline & & 350 & -1.345 & 16 & 1634.7 \\
\hline & & 450 & -0.778 & 21 & 1532.3 \\
\hline & & 550 & -0.490 & 26 & 1470.5 \\
\hline & & 650 & -0.325 & 30 & 1429.9 \\
\hline & & 750 & -0.221 & 35 & 1403.0 \\
\hline & & 850 & -0.152 & 39 & 1384.3 \\
\hline & & 950 & -0.104 & 44 & 1371.7 \\
\hline & & 1050 & -0.068 & 48 & 1363.1 \\
\hline & & 1150 & -0.042 & 53 & 1357.6 \\
\hline & & 1250 & -0.021 & 58 & 1354.5 \\
\hline & & 1350 & -0.005 & 62 & 1353.1 \\
\hline & & 1450 & 0.007 & 66 & 1353.2 \\
\hline & & 1550 & 0.017 & 71 & 1353.5 \\
\hline & & 1650 & 0.026 & 75 & 1356.7 \\
\hline & & 1750 & 0.033 & 80 & 1359.7 \\
\hline & & 1850 & 0.039 & 84 & 1363.3 \\
\hline & & 1950 & 0.044 & 89 & 1367.5 \\
\hline
\end{tabular}




\subsection{SEOQ Sensitivity Analysis with Capital Constraint}

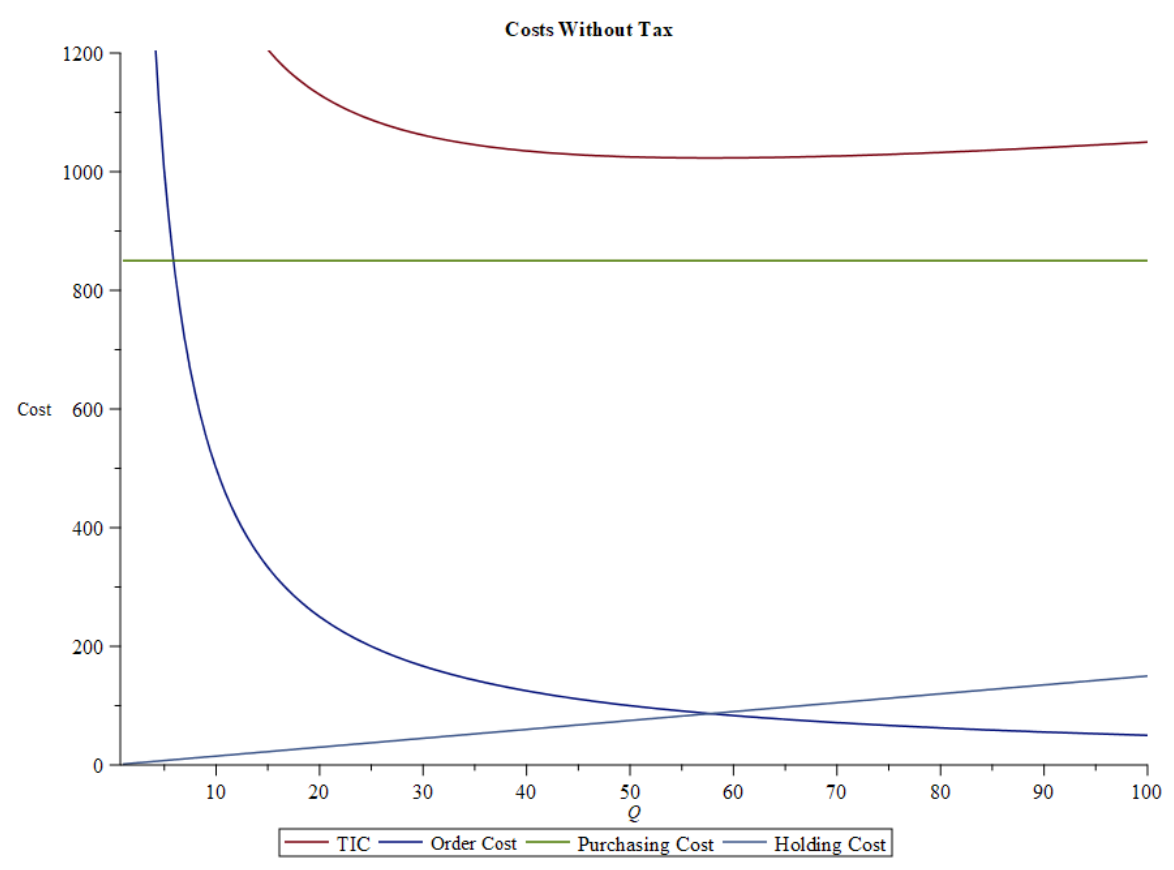

Fig. 1. Sensitivity Graph of TIC SEOQ without Tax

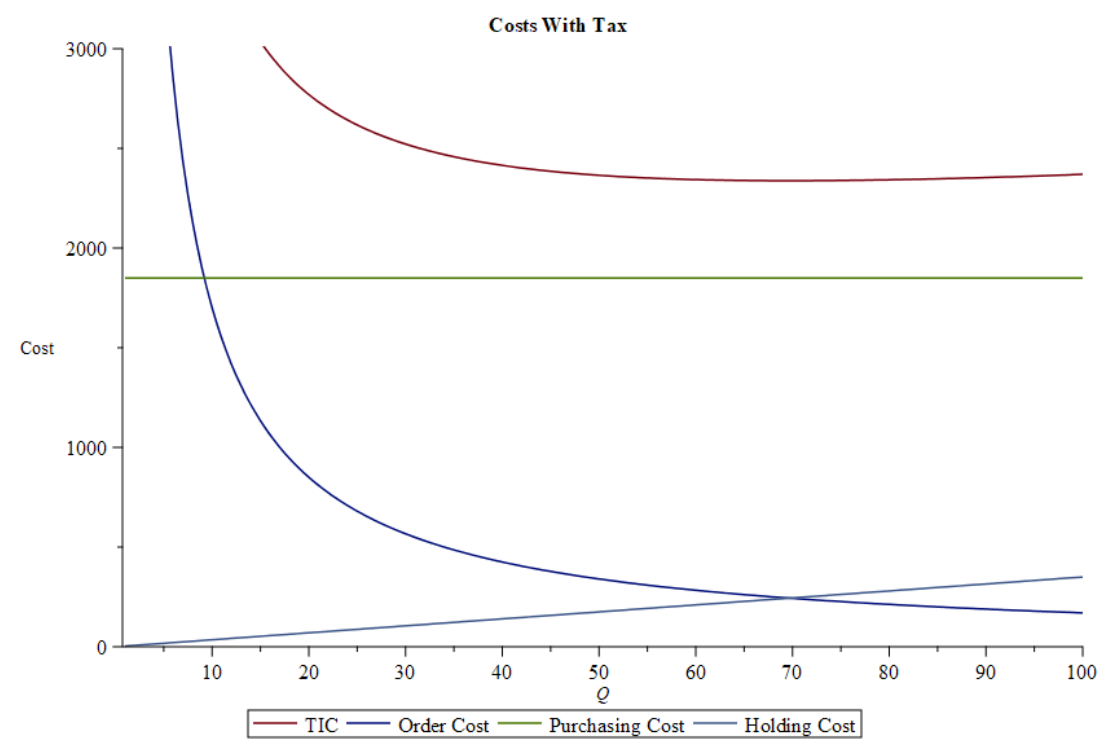

Fig. 2. Sensitivity Graph of TIC SEOQ without Tax

Fig. 1 and Fig. 2 present the effects of lot size (Q) on the inventory cost. The results imply that the order cost and total inventory cost of the SEOQ model are affected by $Q$. For order cost, the greater the value of $Q$, the smaller the cost. It is due to the number of shipping frequencies that gets smaller. Conversely, the smaller the $\mathrm{Q}$ value, the higher the order cost. In terms of inventory cost, the higher the $\mathrm{Q}$ value, the greater the total inventory cost. Conversely, the smaller the value of $\mathrm{Q}$, the smaller the total inventory cost. 


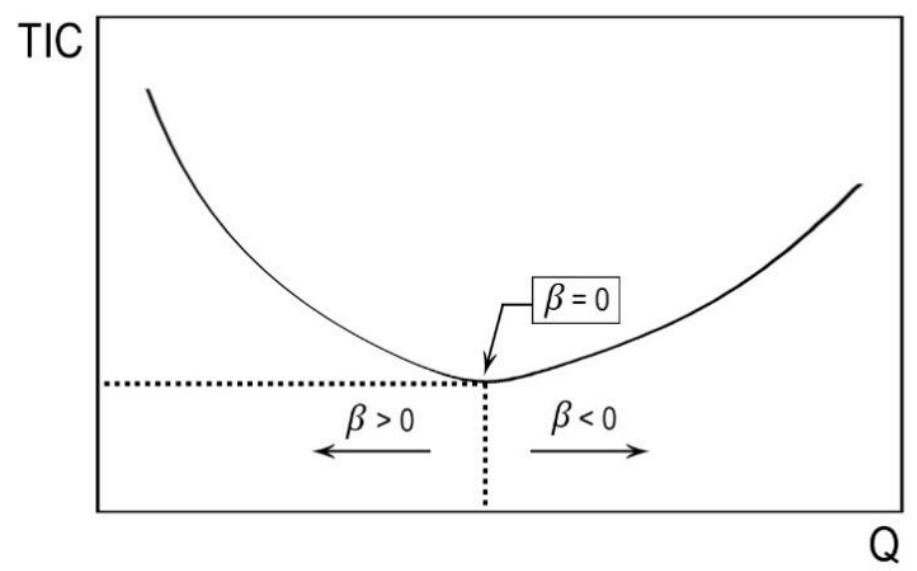

Fig. 3. Correlation between $\beta$ and TIC

\section{Conclusion}

The purpose of this study was to develop a more sophisticated method for solving the problems of determining lot size by considering environmental impact and capital constraint. In this study, the researchers developed SEOQ models by considering capital constraints. Capital itself is the cost used in the process of purchasing raw materials. Capital is an essential aspect that needs to be considered in decision making. This research also presented numerical experiments and analyzed the sensitivity of the models. The experimental results show that the proposed models helped solve the problems. Further, it is suggested that future researchers develop SEOQ models for multi-item products with capital and capacity constraints.

\section{References}

[1] D. M. Utama, "Penentuan Lot Size Pemesanan Bahan Baku Dengan Batasan Kapasitas Gudang," Jurnal Ilmiah Teknik Industri, vol. 15, pp. 64-68, 2016. https://doi.org/10.23917/jiti.v15i1.1664.

[2] D. M. Utama, "Model Penentuan Lot Pemesanan Dengan Mempertimbangkan Unit Diskon dan Batasan Kapasitas Gudang dengan Program Dinamis," Jurnal $\begin{array}{llllll}\text { Teknik Industri, } & \text { vol. } & 18, & \text { p. } & 917 .\end{array}$ https://doi.org/10.22219/JTIUMM.Vol18.No1.94-102.

[3] G. Kim, K. Wu, and E. Huang, "Optimal inventory control in a multi-period newsvendor problem with non-stationary demand," Advanced Engineering Informatics, vol. 29, pp. 139-145, 2015. https://doi.org/10.1016/j.aei.2014.12.002.

[4] D. M. Utama, D. P. Wardani, S. T. Halifah, and D. C. Pradikta, "Model Economic Production Quantity dengan Rework Process dan Batasan Gudang," Jurnal Sistem

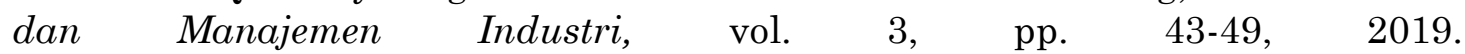
https://doi.org/10.30656/jsmi.v3i1.1017.

[5] P. Hanafizadeh, A. Shahin, and M. Sajadifar, "Robust Wagner-Whitin algorithm with uncertain costs," Journal of Industrial Engineering International, 2018. https://doi.org/10.1007/s40092-018-0298-y.

[6] E. A. Silver, "A Heuristic for Selecting Lot Size Quantities for the Case of a Deterministic Time-Varying Demand Rate and Discrete Opportunities for Replenishment," Prod. Inventory Manage., vol. 2, pp. 64-74, 1973. www.ci.nii.ac.jp/naid/10026018018/en/. 
[7] D. M. Utama, "Model Program Dinamis Untuk Lot Size Multi Item Dengan Kendala Kapasitas Gudang," J@ti Undip : Jurnal Teknik Industri, vol. 14, p. 6, 2019. https://doi.org/10.14710/jati.14.1.21-26.

[8] D. M. Utama, "Model Program Dinamis Dalam Penentuan Lot Pemesanan dengan Mempertimbangkan Batasan Modal," in Prosiding SENTRA (Seminar Teknologi dan Rekayasa), 2017, pp. 1-6. www.researchreport.umm.ac.id/index.php/sentra/article/view/1463.

[9] D. M. Utama, T. Baroto, D. Maharani, F. R. Jannah, and R. A. Octaria, "Algoritma ant-lion optimizer untuk meminimasi emisi karbon pada penjadwalan flow shop dependent sequence set-up," 2019, vol. 9, pp. 69-78, 2019. https://doi.org/10.24960/jli.v9i1.4775.69-78.

[10] D. M. Utama, "An Effective Hybrid Sine Cosine Algorithm to Minimize Carbon Emission on Flow-shop Scheduling Sequence Dependent Setup," 2019, vol. 20, pp. 62-72, 2019. https://doi.org/10.22219/JTIUMM.Vol20.No1.62-72.

[11] D. M. Utama, "Model EOQ Dengan Mempertimbangkan Karbon Emisi dan Batasan Modal," in Prosiding SENTRA (Seminar Teknologi dan Rekayasa), 2019, pp. 73-78. www.research-report.umm.ac.id/index.php/sentra/article/view/3099.

[12] J. Qin, X. Bai, and L. Xia, "Sustainable Trade credit and replenishment policies under the cap-and-trade and carbon tax regulations," Sustainability, vol. 7, pp. 16340-16361, 2015. https://doi.org/10.3390/su71215818.

[13] H. Yang, J. Luo, and H. Wang, "The role of revenue sharing and first-mover advantage in emission abatement with carbon tax and consumer environmental awareness," International Journal of Production Economics, vol. 193, pp. 691-702, 2017. https://doi.org/10.1016/j.ijpe.2017.08.032.

[14] X. Ma, P. Ji, W. Ho, and C.-H. Yang, "Optimal procurement decision with a carbon tax for the manufacturing industry," Computers \& Operations Research, vol. 89, pp. 360-368, 2018. https://doi.org/10.1016/j.cor.2016.02.017.

[15] N. Absi, S. Dauzère-Pérès, S. Kedad-Sidhoum, B. Penz, and C. Rapine, "The singleitem green lot-sizing problem with fixed carbon emissions," European Journal of Operational Research, vol. 248, pp. 849-855, 2016. https://doi.org/10.1016/j.ejor.2015.07.052.

[16] V. Hovelaque and L. Bironneau, "The carbon-constrained EOQ model with carbon emission dependent demand," International Journal of Production Economics, vol. 164, pp. 285-291, 2015. https://doi.org/10.1016/j.ijpe.2014.11.022.

[17] S. Tang, W. Wang, H. Yan, and G. Hao, "Low carbon logistics: Reducing shipment frequency to cut carbon emissions," International Journal of Production Economics, vol. 164, pp. 339-350, 2015. https://doi.org/10.1016/j.ijpe.2014.12.008.

[18] A. A. Taleizadeh, V. R. Soleymanfar, and K. Govindan, "Sustainable economic production quantity models for inventory systems with shortage," Journal of cleaner production, vol. 174, pp. 1011-1020, 2018. https://doi.org/10.1016/j.jclepro.2017.10.222.

[19] D. Battini, A. Persona, and F. Sgarbossa, "A sustainable EOQ model: theoretical formulation and applications," International Journal of Production Economics, vol. 149, pp. 145-153, 2014. https://doi.org/10.1016/j.ijpe.2013.06.026.

[20] X. Chen, S. Benjaafar, and A. Elomri, "The carbon-constrained EOQ," Operations $\begin{array}{lllll}\text { Research Letters, } & \text { vol. } & 41, & \text { pp. } & 172-179,\end{array}$ https://doi.org/10.1016/j.orl.2012.12.003.

[21] M. Y. Jaber, M. Bonney, and H. Jawad, "Comparison between economic order/manufacture quantity and just-in-time models from a thermodynamics point 
of view," Computers \& Industrial Engineering, vol. 112, pp. 503-510, 2017. https://doi.org/10.1016/j.cie.2016.08.023.

[22] P. He, W. Zhang, X. Xu, and Y. Bian, "Production lot-sizing and carbon emissions under cap-and-trade and carbon tax regulations," Journal of Cleaner Production, vol. 103, pp. 241-248, 2015. https://doi.org/10.1016/j.jclepro.2014.08.102.

[23] H. Liao and Q. Deng, "A carbon-constrained EOQ model with uncertain demand for remanufactured products," Journal of Cleaner Production, vol. 199, pp. 334-347, 2018. https://doi.org/10.1016/j.jclepro.2018.07.108.

[24] A. Gurtu, M. Y. Jaber, and C. Searcy, "Impact of fuel price and emissions on inventory policies," Applied Mathematical Modelling, vol. 39, pp. 1202-1216, 2015. https://doi.org/10.1016/j.apm.2014.08.001.

[25] J. Bauer, T. Bektaş, and T. G. Crainic, "Minimizing greenhouse gas emissions in intermodal freight transport: an application to rail service design," Journal of the Operational Research Society, vol. 61, pp. 530-542, 2010. https://doi.org/10.1057/jors.2009.102.

[26] M. C. Arslan and M. Turkay, "EOQ revisited with sustainability considerations," Foundations of Computing and Decision Sciences, vol. 38, pp. 223-249, 2013. https://doi.org/10.2478/fcds-2013-0011.

[27] M. Bonney and M. Y. Jaber, "Environmentally responsible inventory models: Nonclassical models for a non-classical era," International Journal of Production Economics, vol. 133, pp. 43-53, 2011. https://doi.org/10.1016/j.ijpe.2009.10.033.

[28] D.-H. Lee, M. Dong, and W. Bian, "The design of sustainable logistics network under uncertainty," International Journal of Production Economics, vol. 128, pp. 159-166, 2010. https://doi.org/10.1016/j.ijpe.2010.06.009.

[29] P. Letmathe and N. Balakrishnan, "Environmental considerations on the optimal product mix," European Journal of Operational Research, vol. 167, pp. 398-412, 2005. https://doi.org/10.1016/j.ejor.2004.04.025.

[30] T. Penkuhn, T. Spengler, H. Püchert, and O. Rentz, "Environmental integrated production planning for the ammonia synthesis," European Journal of Operational Research, vol. 97, pp. 327-336, 1997. https://doi.org/10.1016/S0377-2217(96)002019.

[31] J. Q. F. Neto, J. M. Bloemhof-Ruwaard, J. A. van Nunen, and E. van Heck, "Designing and evaluating sustainable logistics networks," International Journal of Production Economics, vol. 111, pp. 195-208, 2008. https://doi.org/10.1016/j.ijpe.2006.10.014.

[32] N. Kim, M. Janic, and B. Van Wee, "Trade-off between carbon dioxide emissions and logistics costs based on multiobjective optimization," Transportation Research Record: Journal of the Transportation Research Board, pp. 107-116, 2009. https://doi.org/10.3141/2139-13.

[33] A. Raturi and V. R. Singhal, "Estimating the opportunity cost of capital for inventory investments," vol. 18, pp. 407-413, 1990. https://doi.org/10.1016/03050483(90)90031-4.

[34] M. R. Asadabadi, "A Revision on Cost Elements of the EOQ Model," Studies in Business and Economics, vol. 11, pp. 5-14, 2016. https://doi.org/10.1515/sbe-20160001. 